\title{
Transmission of Moroccan watermelon mosaic virus (MWMV) by Aphids in Greece
}

Elisavet K. Chatzivassiliou, Plant Pathology Laboratory, Faculty of Crop Science, Agricultural University of Athens, 11855 Athens, Greece; Aristeidis P. Papapanagiotou, Department of Agricultural Technology, Technological Education Institute of Western Macedonia, Florina, Greece; Panagiotis D. Mpenardis, Plant Pathology Laboratory, Faculty of Crop Science, Agricultural University of Athens; Dionyssios Ch. Perdikis, Agricultural Zoology and Entomology Laboratory, Faculty of Crop Science, Agricultural University of Athens; and George Menexes, Laboratory of Agronomy, School of Agriculture, Aristotle University of Thessaloniki, Thessaloniki, Greece

\begin{abstract}
Chatzivassiliou, E. K., Papapanagiotou, A. P., Mpenardis, P. D., Perdikis, D. C., and Menexes, G. 2016. Transmission of Moroccan watermelon mosaic virus (MWMV) by aphids in Greece. Plant Dis. 100:601-606.

The aphid-transmitted Moroccan watermelon mosaic virus (MWMV; Potyvirus, Potyviridae) is an emerging pathogen in cucurbit crops in the Mediterranean basin but information on its transmitting vector species is limited. This study aimed to record the competence of 22 species of the Greek aphid fauna to vector MWMV. Timed-probe transmission experiments and arena tests were performed using laboratory colonies of aphid species abundant in field surveys; less common species were tested as apterous individuals collected directly from field plants in mass-inoculation (nonpersistent) tests. Depending on the test, aphids were tested in cohorts of 10 or 20 individuals on zucchini (Cucurbita pepo L.) plants and the frequency of transmission was calculated for a single aphid. Among 12 species tested in timed-probe transmission tests, Myzus persicae nicotianae (74.0\%) appeared to be the most efficient vector, followed by $M$. persicae (48.0\%), Aphis gossypii (11.8\%), an

unidentified Aphis sp. (11.8\%), and A. spiraecola (11.0\%). Alatae of nine species tested in arena tests transmitted the virus in rates varying from 0.7 to $53.6 \%$; M. persicae was the most efficient species in virus spread. In mass-inoculation tests, the probability that apterae of 12 aphid species collected from field plants transmitted MWMV fluctuated from 0.3 to $5.3 \%$. No transmission was obtained by Brevicoryne brassicae. The following species are reported as new vectors of MWMV: A. fabae, A. nerii, A. spiraephaga, A. umbrella, Capitophorus eleaegni, Dysaphis (Pomaphis) pyri, Macrosiphoniella sanborni, Macrosiphum rosae, Myzocallis castanicola, Myzus persicae nicotianae, $M$. cerasi, M. varians, Phorodon humuli, Ovatus crataegarius, Takecallis arundicolens (first report in Greece), Uroleucon sonchi, and U. (Uromelan) aeneum. These results contribute to a better understanding of MWMV epidemiology.
\end{abstract}

In the Mediterranean area, cucurbits (plants of the family Cucurbitaceae) form major economical crops. However, their profitability is threatened due to increased virus diversity and newly emerging viruses (Lecoq and Desbiez 2012). Among the several cucurbitinfecting potyviruses (genus Potyvirus, family Potyviridae), Moroccan watermelon mosaic virus (MWMV) was recently recognized as a distinct member (Lecoq et al. 2001; McKern et al. 1993) that evolved from the watermelon mosaic complex initially consisting of the $\mathrm{Wa}$ termelon mosaic virus (WMV) and the W strain of Papaya ringspot virus (PRSV) (Lecoq and Desbiez 2012; Yakoubi et al. 2008).

Originally discovered in Morocco in 1972 (Fischer and Lockhart 1974) but, at that time, considered a WMV strain, MWMV has spread rapidly during the last decade in the Mediterranean basin (the Canary Islands, Italy, Spain, southern France, and Tunisia), in sub-Saharan Africa (Zimbabwe, Niger, Cameroon, and Sudan), and in South Africa (Lecoq and Desbiez 2012; Lecoq et al. 2008). The recently emerged MWMV isolates from the Mediterranean region share conserved sequences that differ from those originating from western and central Africa and from the southern part of Africa (Lecoq et al. 2001; Yakoubi et al. 2008).

The narrow host range of MWMV includes mainly cucurbits (Arocha et al. 2008; Owolabi et al. 2012). The diseased plants show severe mosaic, dark-green blistering, and deformation of leaves and fruit; plant necrosis is also recorded in several watermelon varieties, resulting in complete crop failure (Lecoq et al. 2001). MWMV is transmitted by aphids in a nonpersistent manner; to date, only a

Corresponding author: E. K Chatzivassiliou; E-mail: echatz@aua.gr

E. K. Chatzivassiliou and A. P. Papapanagiotou contributed equally to this work.

Accepted for publication 5 October 2015.

http://dx.doi.org/10.1094/PDIS-07-15-0805-RE

(C) 2016 The American Phytopathological Society few aphid species are known as its vectors (Owolabi and Ekpiken 2014; Owolabi et al. 2012; van der Meer and Garnett 1987; Yakoubi et al. 2008). No seed transmission has been reported (Roggero et al. 1998).

In Greece, MWMV was identified in 2012 as the causal agent of a severe crop decline and large yield losses of different hybrid varieties of zucchini cultivated in Peloponnese (Ilia and Messinia prefectures, southeastern Greece; Malandraki et al. 2014). It was first observed in zucchini hybrids resistant or tolerant to the most common aphidborne cucurbit viruses such as WMV, Zucchini yellow mosaic virus (ZYMV), and Cucumber mosaic virus (CMV), which are endemic in this area. The virus quickly established in those areas and serious epidemics were also observed in 2013 and 2014 (Malandraki et al 2014; Xanthis et al. 2014) suggesting the presence of one or more competent vectors. Therefore, we studied the transmission competence of 22 native aphid species, in order to evaluate their potential importance to the spread of MWMV in Greek cucurbit crops. Aphid species which occur in high numbers in cucurbit fields were tested in timed-probe transmission experiments and in arena tests, while less abundant species were tested in mass-inoculation tests.

\section{Material and Methods}

Aphid colonies and populations. In total, 22 aphid species were collected from field plants (Table 1), transferred to the lab, and identified according to Blackman and Eastop (2000, 2006). Clones of 12 of the most abundant aphid species or subspecies (Katis et al. 2006; Kavallieratos et al. 2007; Tsitsipis et al. 2007) were established from a single aptera on the host plant from which they were collected. Among the 12 species tested, seven species are known cucurbit colonizers (Blackman and Eastop 2006) (Table 1). Clones were maintained in cages at room temperature $\left(20\right.$ to $\left.22^{\circ} \mathrm{C}\right)$, with a photoperiod of $16 \mathrm{~h}$ of light; different clones of Aphis fabae and A. gossypii were also tested. Two cucurbit-colonizing and 10 noncolonizing aphid species were tested as field populations (e.g., apterous individuals collected directly from field plants; Table 1). In order to confirm that field-collected aphids did not carry any virus, single aphids used to 
establish laboratory clones or a subgroup of 10 apterae used directly in the transmission experiments were placed on healthy zucchini plants for $24 \mathrm{~h}$. Additionally, their field host plant was tested for the presence of cucurbit viruses. Only aphids collected on virusfree hosts that did not transmit any virus to zucchini plants were included in the study.

Plant material and virus isolate. Zucchini (Cucurbita pepo L.) 'Amerigo F1' plants were grown from seed in a greenhouse with insect-proof screens in all openings $\left(25 \pm 2^{\circ} \mathrm{C}\right)$, where plants were checked for the presence of aphids twice a week. Seedlings either were used at the cotyledonary stage as test hosts or were mechanically inoculated with MWMV to be used as source plants 2 weeks later.

An MWMV isolate (MWMV-Gr) was obtained from a field zucchini plant in Ilia prefecture (Peloponnese) that tested serologically positive for MWMV but negative for WMV, ZYMV, CMV, and PRSV, representing the most common nonpersistently transmitted viruses encountered in the Mediterranean countries (Lecoq and Desbiez 2012) as well as in Greece (Xanthis et al. 2014). For the transmission studies, a pure isolate was obtained by nonpersistent transmission tests using a single Myzus persicae (Sulzer) individual per zucchini plant; this original material was kept in $-80^{\circ} \mathrm{C}$ and used for the mechanical inoculation of the source plants in all tests.

Transmission tests. Timed-probe transmission experiments (non persistent transmission tests). Six cucurbit-colonizing, five noncucurbit-

Table 1. Aphid species tested as vectors of Moroccan watermelon mosaic virus and their hosts ${ }^{\mathrm{w}}$

\begin{tabular}{|c|c|}
\hline Species tested ${ }^{x}$ & Host plant \\
\hline \multicolumn{2}{|l|}{ Timed probe and arena } \\
\hline Aphis sp. & $\begin{array}{l}\text { Mandevilla sanderi (Hemsl.) } \\
\text { Woodson }\end{array}$ \\
\hline Aphis fabae Scopoli $(\mathrm{Ch})^{\mathrm{y}}$ & Chenopodium quinoa $\mathrm{L}$. \\
\hline A. fabae Scopoli $(\mathrm{P})^{\mathrm{y}}$ & Phaseolus vulgaris $\mathrm{L}$. \\
\hline A. fabae Scopoli (V) & Vicia faba $\mathrm{L}$. \\
\hline A. gossypii Glover $(\mathrm{C})^{\mathrm{y}}$ & Citrus deliciosa Ten. \\
\hline A. gossypii Glover $(\mathrm{H})^{\mathrm{y}}$ & Hibiscus rosa-sinensis $\mathrm{L}$. \\
\hline A. nerii Boyer de Fonscolombe ${ }^{y}$ & Nerium oleander L. \\
\hline A. spiraecola Patch $^{\mathrm{y}}$ & $\begin{array}{l}\text { Pittosporum toriba (Thunb.) W.T. } \\
\text { Aiton }\end{array}$ \\
\hline Brevicoryne brassicae (L.) & Brassica oleracea L. var. capitata \\
\hline Macrosiphum rosae (L.) & Rosa sp. L. \\
\hline $\begin{array}{l}\text { Macrosiphoniella sanborni } \\
{\text { (Gillette })^{\mathrm{y}}}\end{array}$ & Chrysanthemum sp. L. \\
\hline Myzocallis castanicola Baker & Castanea sativa Mill. \\
\hline Myzus persicae (Sulzer) ${ }^{\mathrm{y}}$ & Capsicum аппиит L. \\
\hline M. persicae nicotianae Blackman & Nicotiana tabacum $\mathrm{L}$. \\
\hline Uroleucon sonchi $(\mathrm{L})$. & Sonchus oleraceus L. \\
\hline \multicolumn{2}{|l|}{ Field populations } \\
\hline A. nerii Boyer de Fonscolombey & Nerium oleander $\mathrm{L}$. \\
\hline A. spiraephaga Müller & Spirae sp. L. \\
\hline A. umbrella (Borner) & Malva sylvestris $\mathrm{L}$. \\
\hline Capitophorus eleaegni del Guercio & Elaeagnus pungens Thunb. \\
\hline $\begin{array}{l}\text { Dysaphis (Pomaphis) pyri } \\
\text { (Boyer de Fonscolombe) }\end{array}$ & Pyrus communis $\mathrm{L}$. \\
\hline $\begin{array}{l}\text { Macrosiphoniella sanborni } \\
\text { (Gillette })^{\mathrm{y}}\end{array}$ & Chrysanthemum morifolium Ramat. \\
\hline Myzus cerasi $\mathrm{F}$. & Prunus avium L. \\
\hline M. varians Davidson & P. persica (L.) Batsch \\
\hline Ovatus crataegarius (Walker) & Cydonia oblonga Mill. \\
\hline Phorodon humuli (Schrank) & Prunus cerassifera Ehrh. 'Pissardii' \\
\hline Takecallis arundicolens $(\text { Clarke })^{\mathrm{z}}$ & Phyllostachys spp. \\
\hline $\begin{array}{l}\text { U. (Uromelan) aeneum Hille Ris } \\
\text { Lambers }\end{array}$ & Cirsium arvense (L.) Scop. \\
\hline \multicolumn{2}{|c|}{$\begin{array}{l}\text { w Species were either tested as laboratory colonies in timed-probe experi- } \\
\text { ments and arena tests or as field populations in mass-inoculation tests. } \\
\times \text { Aphid clones grown on Chenopodium quinoa L. (Ch), Phaseolus vulgaris } \\
\text { L. (P), Vicia faba L. (V), Citrus deliciosa Ten. (C), or Hibiscus rosa-sinensis } \\
\text { L. (H). } \\
\text { y Cucurbit-colonizing species according to Blackman and Eastop (2006). } \\
\text { z First report in Greece. }\end{array}$} \\
\hline
\end{tabular}

colonizing, and one nonidentified Aphis sp. (Table 1) were tested as laboratory colonies; among them, three clones of A. fabae and two of A. gossypii collected and reared on different host species were also tested. Apterous aphids were allowed to acquire MWMV for 3 to 4 min after a starvation period of $2 \mathrm{~h}$. Subsequently, they were transferred in groups of 10 onto a zucchini plant for $24 \mathrm{~h}$. When $100 \%$ transmission was recorded, the respective species were subsequently tested in cohorts of five individuals. Only one aphid per plant was used when testing $M$. persicae and $M$. persicae nicotianae due to its high expected transmission efficiency (Blackman and Eastop 2006).

Arena tests. The propensity (i.e., the natural ability to inoculate a plant with a virus; Irwin and Ruesink 1986; Yuan and Ullman 1996) of Aphis sp., A. fabae (P), A. gossypii (C), A. spiraecola (P), Macrosiphum rosae, Macrosiphoniella sanborni, Myzocallis castanicola, Myzus persicae, and M. persicae nicotianae (Table 1) for MWMV was tested in arena tests. Ten alatae (or five in the case of $100 \%$ transmission) of different ages collected from the laboratory colonies were placed without being starved on an MWMV-infected zucchini plant surrounded by eight healthy ones, inside a cage (50 by 50 by $50 \mathrm{~cm}$ ) with insect-proof screens. Only one aphid per plant was used when testing $M$. persicae and M. persicae nicotianae. Aphids had unrestricted access to the source and indicator plants for the next $24 \mathrm{~h}$.

Mass inoculations. Ten noncucurbit-colonizing and two cucurbitcolonizing aphid species (Table 1) were tested by mass-inoculation tests. Groups of 20 apterous individuals of each species were collected from field plants and tested on each of 10 zucchini plants, as previously described for the timed-probe experiments.

Timed-probed experiments and arena tests were replicated five times with specimens from each colony, while mass inoculations were repeated 10 times for each aphid species. In all tests, a group of plants was challenged with aphids abstaining from virus acquisition (negative control) to confirm virus absence from aphids' colonies or field populations and from test plants. After the end of the transmissions the test, plants were sprayed with imidacloprid at $0.5 \mathrm{ml} /$ liter (Confidor $200 \mathrm{SL}$; Bayer CropScience LP) and transferred to an insect-proof greenhouse for the development of symptoms. Symptoms consisting of interveinal mosaic, chlorosis, and leaf malformation appeared 2 to 3 weeks later and the presence of MWMV was confirmed by double-antibody sandwich enzymelinked immunosorbent assay (DAS-ELISA).

DAS-ELISA tests. DAS-ELISA was used to test field plants for the presence of cucurbit viruses (ZYMV, CMV, MWMV, and PRSV) when identifying the original MWMV isolate, when collecting aphids to be tested directly from field plants, or to detect MWMV in the plants used as acquisition or transmission hosts in our laboratory studies. Tests were run using the respective polyclonal antibodies (Loewe) according to the manufacturer's instructions.

Data analysis. Transmission rates (\%) of the aphid species tested were estimated by the one aphid transmission probability $(P)$ test using the formula $P=1-(1-R / N)^{1 / i}$, where $R$ is the number of the infected receptor plants, $N$ the number of receptor plants used, and $i$ the number of aphids per plant (Gibbs and Gower 1960).

Timed-probe transmission experiments (nonpersistent transmission tests) or arena tests were analyzed with the one-way analysis of variance (ANOVA) method, followed by the Tukey's test for multiple comparisons of means. The same statistical approach was adopted for detecting the differences among aphid populations in mass-inoculation tests. A $t$ test for independent samples was used for pairwise comparisons of means for species tested in both timed-probe and arena experiments (Yuan and Ullman 1996). Prior to the above-mentioned statistical hypothesis, testing procedures data were square root transformed in order to achieve (i) better fit to normal distribution and (ii) homogeneity of variances between the studied populations. Means in tables were computed from the raw untransformed values. All experiments were based on the completely randomized design. The significance level in all hypotheses-testing procedures was preset at $P \leq 0.05$. SPSS v.15.0 software (SPSS Inc.) was used for the statistical analyses. 


\section{Results}

Timed-probe transmission experiments. When laboratory colonies of 12 aphid species were tested, all but Brevicoryne brassicae transmitted MWMV-Gr. This species failed to transmit the virus even when cohorts of 50 individuals per plant were used. When groups of 10 individuals of an A. spiraecola colony reared on Pittosporum toriba and from an unidentified species of the genus Aphis grown on Mandevilla sanderi were tested, rates of $100 \%$ were obtained (data not shown); therefore, those two species were subsequently also tested in groups of five and the obtained results were used for the calculation of their vector efficiency.

The probability of transmission $(\%)$ by single aphids $(P)$ as calculated by the formula described by Gibbs and Gower (1960) ranged from 0.4 to $74.0 \%$, with significant differences among the tested species (ANOVA, $\mathrm{F}_{14 ; 60}=266.5, P<0.001$; Table 2). The most effective vectors were Myzus persicae nicotianae (74.0\%) and M. persicae $(48.0 \%)$; these two species differed in their transmission efficiency. The cucurbit-colonizing A. spiraecola (11.0\%) and A. gossypii from hibiscus $(11.8 \%)$ or citrus $(9.3 \%)$ and an Aphis sp. $(11.1 \%)$ were also vectors with comparable transmission efficiencies. Lower transmission efficiencies were recorded for a group of MWMV vectors, including the cucurbit-colonizing A. fabae clones (2.6 to $5.6 \%$ ) and $A$. nerii $(5.4 \%)$ and the noncucurbitcolonizing Macrosiphum rosae (5.3\%). Different clones of A. gossypii (9.3 to $11.8 \%)$ transmitted MWMV-Gr at similar rates; $A$. fabae from bean $(5.6 \%)$ was more efficient than the respective colony from Chenopodium quinoa (2.6\%). The other vectors-for example, the cucurbit-colonizing Macrosiphoniella sanborni (1.6\%), and the noncucurbit-colonizing Uroleucon sonchi $(0.6 \%)$ and Myzocallis castanicola $(0.4 \%)$ - showed significantly lower transmission efficiencies.

Arena tests. In arena tests, transmission rates showing propensity were lower than those recorded in the timed-probe experiments for all tested species, except for Macrosiphoniella sanborni; however, propensity varied significantly depending on the aphid species (ANOVA; $\mathrm{F}_{8 ; 27}=121.6, P<0.001$; Table 2 ). The most efficient species in spreading MWMV was the polyphagous Myzus persicae (53.6\%), and its propensity was higher than that of $M$. persicae nicotianae $(28.1 \%)$. The propensity of the noncucurbit-colonizing Macrosiphoniella sanborni (7.4\%), the cucurbit-colonizing $A$. spiraecola
(4.1\%), or an Aphis sp. (6.7\%) were comparable (for the different comparisons, $P$ values ranged from 0.256 to 1.00$)$. Other cucurbitcolonizing species such as A. gossypii (C) $(2.1 \%)$ and A. fabae $(\mathrm{P})$ $(1.7 \%)$ or the noncucurbit-colonizing Macrosiphum rosae $(2.1 \%)$ showed similar propensity (for all comparisons, $P=1.000$ ). Myzocallis castanicola $(1.0 \%)$ was the least successful species in spreading MWMV.

Timed-probe transmission experiments versus arena tests. For the nine aphid species tested in both timed-probe experiments and arena tests (Table 2), virus efficiency and propensity was compared by a $t$ test at $P<0.05$. These values did not differ for Myzus persicae $\left(t_{7}=1.24, P=0.255\right)$ and Myzocallis castanicola $\left(t_{7}=0.42, P=\right.$ 0.682). For Aphis sp. $\left(t_{7}=5.77, P<0.05\right)$, A. fabae $(\mathrm{P})\left(t_{7}=6.82\right.$, $P<0.001)$, A. gossypii (C) $\left(t_{7}=10.11, P<0.001\right)$, A. spiraecola (P) $\left(t_{7}=5.66, P<0.05\right)$, Macrosiphum rosae $\left(t_{7}=5.73, P<0.05\right)$, and Myzus persicae nicotianae $\left(t_{7}=11.27, P<0.001\right)$, transmission efficiency was higher than virus propensity. By contrast, Macrosiphoniella sanborni $\left(t_{7}=9.50, P<0.001\right)$ alatae individuals transmitted MWMV more efficiently than apterae.

Mass inoculations. All 12 species tested as field populations in mass-inoculation tests (cohorts of 20 individuals) transmitted the virus but differences were recorded when their probability of transmission $(\%)$ by single aphids was calculated (ANOVA $F_{11 ; 108}=104.6$, $P<0.001$; Table 3). The transmission of MWMV recorded for the noncucurbit-infesting Phorodon humuli (probability of transmission by single aphids $=5.3 \%$ ) was significantly higher than any other species tested in mass-inoculation experiments when compared using Tukey's test at $P<0.05$. Accordingly, the noncucurbit-colonizing Myzus varians (3.9\%), A. spiraephaga (3.3\%), and Dysaphis pyri $(3.0 \%)$ transmitted at a rate that did not significantly differ from that of the cucurbit-colonizing A. nerii $(3.7 \%)$. The lowest probability among the tested populations was calculated for Macrosiphoniella sanborni $(0.3 \%)$, known to infest cucurbits, and did not significantly differ from noncucurbit-infesting A. umbrella ( $0.4 \%)$, while Ovatus crataegarius $(0.6 \%)$, Takecallis arundicolens $(0.7 \%)$, and Myzus cerasi $(0.9 \%)$ showed comparable transmission rates.

\section{Discussion}

Aphids (Hemiptera: Aphididae) represent a major group of plant virus vectors (Katis et al. 2007). Additionally, nonpersistent virus

Table 2. Transmission of Moroccan watermelon mosaic virus to zucchini plants (Jedida F1) by different aphid species tested in timed-probe experiments (apterae) or arena tests (winged individuals) and the probability that an aphid infected a plant (Gibbs and Gower 1960) ${ }^{\mathrm{u}}$

\begin{tabular}{|c|c|c|c|c|}
\hline \multirow[b]{2}{*}{ Species $^{v}$} & \multicolumn{2}{|c|}{ Timed-probe experiments } & \multicolumn{2}{|c|}{ Arena tests } \\
\hline & Number of infected plants ${ }^{w}$ & One aphid probability $(\%)^{x}$ & Number of infected plantsw & One aphid probability $(\%)^{\mathrm{x}}$ \\
\hline Aphis sp. & $25(48)^{*}$ & $11.8( \pm 1.0) \mathrm{c}$ & $9(32) *$ & $6.7( \pm 1.6) \mathrm{c}$ \\
\hline A. fabae $(\mathrm{Ch})^{\mathrm{y}}$ & $7(50)$ & $2.6( \pm 0.8) \mathrm{fg}$ & - & - \\
\hline A. fabae $(\mathrm{P})^{\mathrm{y}}$ & $13(38)$ & $5.6( \pm 1.0) \mathrm{de}$ & $4(32)$ & $1.7( \pm 0.8) \mathrm{de}$ \\
\hline A. fabae $(\mathrm{V})^{\mathrm{y}}$ & $11(49)$ & $4.2( \pm 1.0)$ ef & - & - \\
\hline A. gossypii $(\mathrm{C})^{\mathrm{y}}$ & $29(50)$ & $9.3( \pm 1.2) \mathrm{cd}$ & $5(32)$ & $2.1( \pm 0.9) \mathrm{de}$ \\
\hline A. gossypii $(\mathrm{H})^{\mathrm{y}}$ & $27(45)$ & $11.8( \pm 1.3) \mathrm{c}$ & - & - \\
\hline A. nerii $^{\mathrm{y}}$ & $17(50)$ & $5.4( \pm 0.9) \mathrm{e}$ & - & - \\
\hline A. spiraecola ${ }^{\mathrm{y}}$ & $15(49) *$ & $11.0( \pm 1.8) \mathrm{c}$ & $4(32) *$ & $4.1( \pm 1.7) \mathrm{cd}$ \\
\hline B. brassicae & $0(50)$ & $0.0( \pm 0.0) \mathrm{i}$ & - & - \\
\hline Myzocallis castanicola & $3(50)$ & $0.4( \pm 0.5) \mathrm{i}$ & $2(32)$ & $0.7( \pm 0.8) \mathrm{e}$ \\
\hline M. persicae ${ }^{\mathrm{y}}$ & $19(50) * *$ & $48.0( \pm 8.4) \mathrm{b}$ & $16(28) * *$ & $53.6( \pm 4.1) \mathrm{a}$ \\
\hline M. p. nicotianae & $23(48) * *$ & $74.0( \pm 5.5) \mathrm{a}$ & $7(32) * *$ & $28.1( \pm 6.3) b$ \\
\hline Macrosiphum rosae & $15(50)$ & $5.3( \pm 0.8)$ ef & $4(32)$ & $2.1( \pm 0.9)$ de \\
\hline Macrosiphoniella sanborni ${ }^{\mathrm{y}}$ & $7(50)$ & $1.6( \pm 0.5) \mathrm{gh}$ & $17(32)$ & $7.4( \pm 1.3) \mathrm{c}$ \\
\hline U. sonchi & $3(50)$ & $0.6( \pm 0.6) \mathrm{hi}$ & - & - \\
\hline ANOVA $^{z}$ & $F_{14 ; 60}=266.5$ & $P<0.001$ & $\mathrm{~F}_{8 ; 27}=121.6$ & $P<0.001$ \\
\hline
\end{tabular}

u Aphids were tested in cohorts of 10 individuals per zucchini plant, except where otherwise stated. Numbers followed by different letters within each column are statistically significant different according to Tukey's test at $P<0.05 ;-$ indicates not performed.

$\checkmark$ Aphid clones grown on Chenopodium quinoa L. (Ch), Phaseolus vulgaris L. (P), Vicia faba L. (V), Citrus deliciosa Ten. (C), or Hibiscus rosa-sinensis L. (H),

${ }^{w}$ Total number of infected plants (10 aphids/plant). An asterisk $\left(^{*}\right)$ indicates tests performed with 5 aphids/plant and double asterisks (**) those with 1 aphid/plant. The total number of tested plants is shown in parentheses.

${ }^{x}$ Estimated probability of transmission by single aphids (and standard deviation in parenthesis) calculated according to the formula of Gibbs and Gower (1960).

y Cucurbit-colonizing species according to Blackman and Eastop (2006).

${ }^{z}$ Analysis of variance. 
transmission tends not to be vector specific; it is characterized by brief probing times for virus acquisition and transmission. Therefore, both colonizing and noncolonizing (transient) aphid species may be involved in virus spread. Almost all species tested in our study were able to transmit MWMV but the rate of transmission differed depending on the species or clone of aphid and the test performed.

Thus far, only four cucurbit-colonizing aphid species had been recorded as MWMV vectors. $M$. persicae (the green peach aphid) transmitted virus isolates from south Africa (van der Meer and Garnett 1987), and it was compared with A. gossypii (the melon or cotton aphid) in transmitting isolates from Tunisia (Yakoubi et al. 2008) and Nigeria (Owolabi et al. 2012), while A. spiraecola (the spirae or citrus green aphid) and Macrosiphum euphorbiae (Thomas) (the potato aphid) were used in transmission experiments in Nigeria (Owolabi et al. 2012; Owolabi and Ekpiken 2014). In our study, we tested and confirmed the vector ability of the first three species, although the rates we obtained differed from those already reported. Several factors such as virus isolate, acquisition and transmission hosts, aphid population, or biotype may affect the efficiency of the transmission (Katis et al. 2007) and, therefore, may contribute to the observed differences.

Myzus persicae and its tobacco-adapted subspecies M. persicae nicotianae (Eastop and Blackman 2005; Margaritopoulos et al. 2007) appeared to be the most competent vectors of MWMV in all tests, reaching transmission rates of 74.0 and $48.0 \%$, respectively. This is not surprising because the polyphagous $M$. persicae is known to be one of the most efficient vectors of more than 100 viruses (Blackman and Eastop 2006). M. persicae transmitted isolates Cuc-45 from South Africa (van der Meer and Garnett 1987) and MWMV-Tn (Owolabi et al. 2012), both at rates of 100\%; however, in those studies, 15 or 5 aphids per inoculation host were used, respectively, compared with the single-aphid test we were applying. Two competent vectors of MWMV we also recorded were A. gossypii (efficiency of MWMV transmission of up to $11.8 \%$ ) and A. spiraecola $(11.0 \%)$, which are known to be implicated in the transmission of several plant viruses (Blackman and Eastop 2006). In previous studies, transmission rates of $90 \%$ were reported for the isolate MWMV-Tn by A. gossypii using groups of five aphids (Yakoubi et al. 2008). Owolabi and Ekpiken (2014) recently showed that

Table 3. Mean probability that an aphid infected a zucchini plant (Amerigo F1) with Moroccan watermelon mosaic virus (Gibbs and Gower 1960) for different aphid species in mass transmission experiments ${ }^{\mathrm{v}}$

\begin{tabular}{|c|c|c|}
\hline Aphid species & $\begin{array}{l}\text { Number of infected } \\
\text { plants }^{w}\end{array}$ & $\begin{array}{c}\text { One aphid probability } \\
(\%)^{x}\end{array}$ \\
\hline Phorodon humuli & $66(100)$ & $5.3( \pm 0.7) \mathrm{a}$ \\
\hline Myzus varians & $55(100)$ & $3.9( \pm 0.6) b$ \\
\hline Aphis nerii ${ }^{\mathrm{y}}$ & $53(100)$ & $3.7( \pm 0.7) b$ \\
\hline A. spiraephaga & $48(100)$ & $3.2( \pm 0.4) b$ \\
\hline $\begin{array}{l}\text { Dysaphis (Pomaphis) } \\
\text { pyri }\end{array}$ & $45(100)$ & $3.0( \pm 0.5) b$ \\
\hline $\begin{array}{l}\text { Uroleucon (Uromelan) } \\
\text { aeneum }\end{array}$ & $22(100)$ & $1.2( \pm 0.3) \mathrm{c}$ \\
\hline Capitophorus eleaegni & $19(100)$ & $1.1( \pm 0.3) \mathrm{cd}$ \\
\hline M. cerasi & $16(100)$ & $0.9( \pm 0.3) \mathrm{cd}$ \\
\hline Takecallis arundicolens & $13(100)$ & $0.7( \pm 0.3) \mathrm{cde}$ \\
\hline Ovatus crataegarius & $11(100)$ & $0.6( \pm 0.2) \mathrm{de}$ \\
\hline A. umbrella & $8(100)$ & $0.4( \pm 0.2)$ ef \\
\hline $\begin{array}{l}\text { Macrosiphoniella } \\
\text { sanborni }^{\mathrm{y}}\end{array}$ & $6(100)$ & $0.3( \pm 0.3) \mathrm{f}$ \\
\hline ANOVA $^{z}$ & $F_{11 ; 108}=104.6$ & $P<0.001$ \\
\hline
\end{tabular}

$\checkmark$ Aphids were tested in cohorts of 20 individuals per plant. Numbers followed by different letters are statistically significant different according to Tukey's test at $P<0.05$.

${ }^{w}$ Total number of infected plants (20 aphids/plant) and, in parentheses, the total number of tested plants in 10 repetitions.

${ }^{x}$ Estimated probability of transmission (\%) by single aphids (and standard deviation in parenthesis) calculated according to the formula of Gibbs and Gower (1960)

y Cucurbit-colonizing species according to Blackman and Eastop (2006).

$\mathrm{z}$ Analysis of variance.
MWMV transmission by A. spiraelola is affected by aphid clone and virus strain. This may explain why transmission of two isolates (MWMV-cor and MWMV-lag) from Nigeria by local A. spiraecola clones were higher (up to $40 \%$ ) than the $11.0 \%$ we recorded for MWMV-Gr isolate by a Greek clone of the same species.

The cucurbit colonizers A. fabae, A. nerii, and Macrosiphoniella sanborni (the bean, oleander, and chrysanthemum aphid, respectively) and Myzus persicae nicotianae are recorded here as new vectors of MWMV. Transmission rates similar to those of A. spiraecola and A. gossypii were also obtained by an Aphis sp. collected on Brazilian jasmine (Mandevilla sanderi). In our tests, the two forms of Myzus persicae appeared to significantly differ in their transmission ability and propensity, although they were tested under the same experimental conditions. These two subspecies differ in their host range and preferences (Eastop and Blackman 2005; Margaritopoulos et al. 2007) and such differences may affect their probing behavior (Ramírez and Niemeyer 2000) and, therefore, nonpersistent virus transmission. Accordingly, some differences were recorded for $A$. fabae clones as were recently observed for A. spiraecola (Owolabi and Ekpiken 2014); however, A. gossypii clones we tested showed comparable transmission rates. In addition to the above-mentioned species, the noncucurbit-colonizing A. spiraephaga, A. umbrella, Capitophorus eleaegni, D. pyri, Myzocallis castanicola, Myzus cerasi, M. varians, O. crataegarius, P. humuli, T. arundicolens (first report in Greece), and U. aeneum are first reported as MWMV vectors. Among the aphids tested, only B. brassicae failed to transmit MWMV; this species has a host range restricted to Brassica spp. (Blackman and Eastop 2006) and, therefore, may abstain from probing on the infected zucchini plant during the given acquisition time period. Overall, 15 new aphid vectors of MWMV were recorded in this study, of which three are cucurbit colonizers (A.fabae, A. nerii, and Macrosiphoniella sanborni) and 12 noncucurbit colonizers (Blackman and Eastop 2006).

For potyviruses, both colonizing and noncolonizing aphid species are capable of transmitting (Katis et al. 2006; Yuan and Ullman 1996); therefore, apart from vector competence, field spread is greatly affected by aphid population composition and flying activity. In this study, we employed different types of experiments (mass inoculations and timed-probe experiments); therefore, direct comparisons including all tested species cannot be performed. However, it is obvious that the most competent MWMV vectors we recorded, such as Myzus persicae, M. persicae nicotianae, A. gossypii, A. spiraecolla, A. fabae, and A. nerii, are cucurbit colonizers. Field populations of colonizing species mainly consist of apterous individuals that migrate over small distances by walking among neighboring plants (Lombaert et al. 2006). However, an increase in density (Hodgson 1981) or behavioral responses to several environmental factors, including host changes induced by virus infection, may trigger alatae proliferation and mobility (Colvin et al. 2006). The infection of ZYMV induces the production of A. gossypii alatae on zucchini plants (Blua and Perring 1992a) affecting virus spread. These aphids, when migrating in large numbers from infected crops, may cause extensive primary infections in adjacent fields. On the other hand, the fact that noncucurbit-colonizing species such as Macrosiphum rosae and $P$. humuli are also potent MWMV vectors cannot be overlooked. Because aphids discriminate between host and nonhost plants only after probing (Powell et al. 2006), noncucurbitcolonizing species have the same probability to transmit under natural conditions. In fact, those species are presumably more likely to acquire and therefore transmit MWMV over larger distances as they alight and repeatedly probe on different plants during host finding (Fereres and Moreno 2009).

In this study, apart from timed-probe experiments that evaluated transmission competence by testing apterous aphids, for the most common aphid species we also employed arena tests that better reflect propensity (i.e., vector importance under field conditions by testing alatae; Irwin and Ruesink 1986; Yuan and Ullman 1996). For most of the species we tested, propensity was lower than efficiency as recorded in other similar studies (Katis et al. 2006; Yuan 
and Ullman 1996); only Macrosiphoniella sanborni performed significantly better in the arena tests. The absence of a starving period that affected aphid probing (Ramírez and Niemeyer 2000) may have contributed to the lower transmission rates recorded in the arenas. Depending on the aphid species, probing behavior may also differ between apterous and alatae individuals; Boquel et al. (2011) showed that both forms of Macrosiphum euphorbiae whereas only apterous of Myzus persicae readily accepted potato as a host. This could explain the differences observed in the ranking of the two biotypes of $M$. persicae; vector efficiency of $M$. persicae nicotianae was higher but vector propensity of $M$. persicae prevailed.

In nature, virus dissemination by alatae aphids is, in fact, a complicated phenomenon depending on multiple factors that affect aphid flight behavior, host selection, and probing response (Fereres and Moreno 2009; Powell et al. 2006). For instance, visiting a nonsuitable host favors migration of an aphid species and, therefore, stimulates the spread of nonpersistent viruses; it is shown that A. fabae alatae can discriminate between a host within a 5-min period, and $75 \%$ of those that alight on an unsuitable plant take off (Hardie and Powell 2002). Recently, it has been proposed that some viruses may induce changes in plant traits that directly and indirectly alter the behavior of their vectors, further enhancing their spread (Ingwell et al. 2012; Mauck et al. 2012); CMV increases attractiveness of infected squash plants while reducing their quality, stimulating rapid emigration of $M$. persicae and A. gossypii alatae after probing (Carmo-Sousa et al. 2014; Mauck et al. 2010, 2012). Increased probing but reduced colonization is also recorded for A. gossypii on ZYMV-infected zucchini plants (Blua and Perring 1992b), while Rhopalosiphum maidis reside for a shorter time on Soybean mosaic virus-infected soybean plants (Fereres et al. 1999). On the other hand, M. presicae settling is not significantly affected by Potato virus $Y$ infection (Castle et al. 1998), whereas an increased preference of aphids for infected compared with healthy plants that may limit further virus spread occasionally can be recorded. Such an effect, however, is usually recorded for persistently transmitted viruses (Colvin et al. 2006; Mauck et al. 2012). Our results indicated that $M$. persicae and $M$. persicae nicotianae are by far more efficient in arenas as well; therefore, they may play a major role in MWMV spread in the field. However, it cannot be excluded that less efficient vectors may migrate in large numbers through cucurbit fields during the growing season, also affecting virus spread. In Greece, A. gossypii is known as the major aphid species flying in Greek cucurbits, while M. persicae and A. spiraecola also appear in large numbers (Katis et al. 2006) and, therefore, are expected to contribute in virus spread. Less frequent species such Macrosiphoniella sanborni, A. fabae, A. nerii, and Macrosiphum rosae (Katis et al. 2006), showing lower propensity in our tests, may presumably be less important in virus spread. However, when these species represent early flyers or they are overwintering on infected hosts, they can play a major role in virus epidemiology.

Within the aim of this study to understand MWMV epidemiology in Greece, we recorded several native aphid species as new and competent MWMV vectors. This virus is highly specialized, and alternative hosts rarely serve as potential MWMV reservoirs. Therefore, winter greenhouse crops are expected to act as virus overwintering sources; these crops, when infested by aphids, can trigger the onset of the epidemic. On the other hand, in some areas, cucurbits may be cultivated in two or three successive crops, resulting in an accumulation of virus sources and vector populations. This scenario may explain the quick and efficient establishment of MWMV in the southwest of the country and must be taken into consideration when planning an integrated approach for virus control.

\section{Literature Cited}

Arocha, Y., Vigheri, N., Nkoy-Florent, B., Bakwanamaha, K., Bolomphety, B., Kasongo, M., Betts, P., Monger, W. A., Harju, V., Mumford, R. A., and Jones, P. 2008. First report of the identification of Moroccan watermelon mosaic virus in papaya in Democratic Republic of Congo. Plant Pathol. $57: 387$
Blackman, R. L., and Eastop, V. F. 2000. Aphids of the World's Crops: An Identification and Information Guide, 2nd ed. John Wiley \& Sons Ltd, London.

Blackman, R. L., and Eastop, V. F. 2006. Aphids on the World's Herbaceous Plants and Shrubs. John Wiley \& Sons Ltd., West Sussex, UK.

Blua, M. J., and Perring, T. M. 1992a. Alatae production and population increase of aphid vectors on virus-infected host plants. Oecologia 92:65-70.

Blua, M. J., and Perring, T. M. 1992b. Effects of Zucchini yellow mosaic virus on colonization and feeding behavior of Aphis gossypii (Homoptera: Aphididae) alatae. Environ. Entomol. 21:578-585.

Boquel, S., Giordanengo, P., and Ameline, A. 2011. Probing behavior of apterous and alate morphs of two potato-colonizing aphids. J. Insect Sci. 11, Article 164. doi:10.1673/031.011.1640.

Carmo-Sousa, M., Moreno, A., Garzo, E., and Fereres, A. 2014. A non-persistently transmitted-virus induces a pull-push strategy in its aphid vector to optimize transmission and spread. Virus Res. 186:38-46.

Castle, S. J., Mowry, T. M., and Berger, P. H. 1998. Differential settling by Myzus persicae (Homoptera: Aphididae) on various virus-infected host plants. Ann. Entomol. Soc. Am. 91:661-667.

Colvin, J., Omongo, C. A., Govindappa, M. R., Stevenson, P. C., Maruthi, M. N., Gibson, G., Seal, S. E., and Muniyappa, V. 2006. Host-plant viral infection effects on arthropod-vector population growth, development and behaviour: Management and epidemiological implications. Adv. Virus Res. 67:419-452.

Eastop, V. F., and Blackman, R. L. 2005. Some new synonyms in Aphididae (Hemiptera: Sternorrhyncha). Zootaxa 1089:1-36.

Fereres, A., Kampmeier, G. E., and Irwin, M. E. 1999. Aphid attraction and preference for soybean and pepper plants infected with potyviridae. Ann. Entomol. Soc. Am. 92:542-548.

Fereres, A., and Moreno, A. 2009. Behavioural aspects influencing plant virus transmission by homopteran insects. Virus Res. 141:158-168.

Fischer, H. U., and Lockhart, B. E. L. 1974. Serious losses in cucurbits caused by Watermelon mosaic virus in Morocco. Plant Dis. Rep. 58:143-146.

Gibbs, A. J., and Gower, J. C. 1960. The use of multiple transfer method in plant virus transmission studies. Some statistical points arising in the analysis of results. Ann. Appl. Biol. 48:75-83.

Hardie, J., and Powell, G. 2002. Video analysis of aphid flight behaviour. Comput Electron. Agric. 35:229-242.

Hodgson, C. J. 1981. Effects of infection with the cabbage black ringspot strain of turnip mosaic virus on turnip as a host to Myzus persicae and Brevieoryne brassicae. Ann. Appl. Biol. 98:1-14.

Ingwell, L. L., Eigenbrode, S. D., and Bosque-Pérez, N. A. 2012. Plant viruses alter insect behaviour to enhance their spread. Online publication. Sci. Rep. 2, Article 578. doi:10.1038/srep00578

Irwin, M. E., and Ruesink, W. G. 1986. Vector intensity: A product of propensity and activity. Pages 13-33 in: Plant Virus Epidemics: Monitoring, Modelling and Predicting Outbreaks. G. D. McLean, R. G. Garrett, and W. G. Ruesink eds. Academic Press, Sydney, Australia.

Katis, N. I., Tsitsipis, J. A., Lykouressis, D. P., Papapanayotou, A., Kokinis, G. M. Perdikis, D. C., and Manoussopoulos, I. N. 2006. Transmission of Zucchini yellow mosaic virus by colonizing and non-colonizing aphids in Greece and new aphid vectors of the virus. J. Phytopathol. 154:293-302.

Katis, N. I., Tsitsipis, J. A., Stevens, M., and Powell, G. 2007. Transmission of plant viruses. Pages 353-390 in: Aphids as Crop Pests. H. van Emden and R. Harrington eds. CAB International, Wallingford, UK.

Kavallieratos, N., Tomanović, Ž., Sarlis, P. G., Vayias, B. J., Žikić, V., and Emmanouel, N. E. 2007. Aphids (Hemiptera: Aphidoidea) on cultivated and self-sown plants in Greece. Biologia 62:335-344.

Lecoq, H., Dafalla, G., Desbiez, C., Wipf-Scheibel, C., Delecolle, B., Lanina, T., Ullah, Z., and Grumet, R. 2001. Biological and molecular characterization of Moroccan watermelon mosaic virus and a potyvirus isolate from Eastern Sudan. Plant Dis. 85:547-552.

Lecoq, H., and Desbiez, C. 2012. Viruses of cucurbit crops in the Mediterranean region: An ever-changing picture. Adv. Virus Res. 84:67-126.

Lecoq, H., Justafré, I., Wipf-Scheibel, C., and Desbiez, C. 2008. Moroccan watermelon mosaic virus newly reported on zucchini squash in France. Plant Pathol. 57:766

Lombaert, E., Boll, R., and Lapchin, L. 2006. Dispersal strategies of phytophagous insects at a local scale: Adaptive potential of aphids in an agricultural environment. BMC Evol. Biol. 6:75-88.

Malandraki, I., Vassilakos, N., Xanthis, C., Kontosfiris, G., Katis, N. I., and Varveri, C. 2014. First report of Moroccan watermelon mosaic virus in zucchini crops in Greece. Plant Dis. 98:702.

Margaritopoulos, J. T., Malarky, G., Tsitsipis, J. A., and Blackman, R. L. 2007 Microsatellite DNA and behavioural studies provide evidence of hostmediated speciation in Myzus persicae (Hemiptera: Aphididae). Biol. J. Linn. Soc. 91:687-702.

Mauck, K., Bosque-Pérez, N. A., Eigenbrode, S. D., De Moraes, C., and Mescher, M. 2012. Transmission mechanisms shape pathogen effects on host-vector interactions: Evidence from plant viruses. Funct. Ecol. 26:1162-1175.

Mauck, K., De Moraes, C. M., and Mescher, C. 2010. Deceptive chemical signals induced by a plant virus attract insect vectors to inferior hosts. Proc. Natl. Acad Sci. USA 107:3600-3605. 
McKern, N. M., Strike, P. M., Barnett, O. W., Ward, C. W., and Shukla, D. D. 1993. Watermelon mosaic virus-Morocco is a distinct potyvirus. Arch. Virol. 131:467-473.

Owolabi, A. T., and Ekpiken, E. E. 2014. Transmission efficiency of two strains of Moroccan watermelon mosaic virus by two clones of Aphis spiraecola (Patch). Int. J. Virol. 10:253-262.

Owolabi, A. T., Rabenstein, F., Ehrig, F., Edgar, M. M., and Vetten, H. J. 2012. Strains of Moroccan watermelon mosaic virus isolated from Lagenaria breviflorus and Coccinia barteri in Calabar, Southeastern Nigeria. Int. J. Virol. 8:258-270.

Powell, G., Tosh, C. R., and Hardie, J. 2006. Host plant selection by aphids: Behavioral, evolutionary, and applied perspectives. Annu. Rev. Entomol. 51:309-330.

Ramírez, C. C., and Niemeyer, H. M. 2000. The influence of previous experience and starvation on aphid feeding behavior. J. Insect Behav. 13:699-709.

Roggero, P., Dellavalle, G., Lisa, V., and Stravato, V. M. 1998. First report of Moroccan watermelon mosaic potyvirus in zucchini in Italy. Plant Dis. 82:351.
Tsitsipis, J. A., Katis, N. I., Margaritopoulos, J. T., Lykouressis, D. P., Avgelis, A. D., Gargalianou, I., Zarpas, K. D., Perdikis, D. C., and Papapanayotou, A 2007. A contribution to the aphid fauna of Greece. Bull. Instectol. 60:31-38.

van der Meer, F. W., and Garnett, H. M. 1987. Purification and identification of a South African isolate of Watermelon mosaic virus-Morocco. J. Phytopathol. 120:255-270.

Xanthis, C. K., Maliogka, V. I., and Katis, N. I. 2014. Incidence of aphid-borne viruses in cucurbit crops in Greece. Page 135 in: Proc. 14th Cong. Mediterr. Phytopathol. Union, Istanbul, Turkey.

Yakoubi, S., Desbiez, C., Fakhfakh, H., Wipf-Scheibel, C., Marrakchi, M., and Lecoq, H. 2008. Biological characterization and complete nucleotide sequence of a Tunisian isolate of Moroccan watermelon mosaic virus. Arch. Virol. 153:117-125

Yuan, C., and Ullman, D. E. 1996. Comparison of efficiency and propensity as measures of vector importance in zucchini yellow mosaic potyvirus transmission by Aphis gossypii and A. craccivora. Phytopathology 86:698-703. 